\title{
Tempering Heat Treatment Effects on Steel Welds
}

\author{
A.V. Adedayo ${ }^{1,3}$, S.A. Ibitoye ${ }^{1}$ and O.O. Oluwole ${ }^{2}$ \\ ${ }^{1}$ Materials Science and Engineering Department, Obafemi Awolowo University, Ile-Ife, \\ Nigeria \\ ${ }^{2}$ Mechanical Engineering Department, University of Ibadan, Ibadan, Nigeria \\ ${ }^{3}$ Metallurgical Engineering Department, Kwara State Polytechnic, PMB 1375, Ilorin, \\ Nigeria \\ *Corresponding author: adelekeadedayo58@yahoo.com
}

\begin{abstract}
This paper reports investigations made on the tempering heat treatment effects on steel welds. The properties of the weld investigated were hardness value and toughness. Micro examination of the samples was also done with optical microscopy. Four (4) different grades of steel rods in $10 \mathrm{~mm}$ diameter were obtained. The range of the carbon contents of the steel rods was from 0.16 wt\% C to 0.33 wt \% C. From each grade of the steel materials, grooved specimen of about 150 $\mathrm{mm}$ were prepared. The grooves were then filled to create welds using arc welding. A set of the resulting welds were then subjected to tempering heat treatment. The hardness values and toughness of the welds were determined. The microstructural analyses of the welds were carried out as well. The results show that hardness and toughness were dependent on the carbon content. There was also significant microstructural modification due to heat treatment.
\end{abstract}

Keywords: $\quad$ Welding, Tempering, Heat treatment, Hardness, Toughness, Microstructure

\section{INTRODUCTION}

Normally, during the arc welding process, the peak temperature varies from near the melting point to the lower critical temperature. The duration of the cycle is very short relative to normal soaking times in heat treating cycles. At high peak temperatures near the fusion line, diffusion is more rapid and the solute atoms, especially carbon, disperse uniformly in the austenite [1]. Also, austenite grain growth occurs. At lower peak temperatures, slightly above the austenite 
transformation temperature, carbides may not be completely dissolved in the austenite. Furthermore, the solute atoms that do dissolve because of the relatively low temperature may not diffuse far from the original site of the carbide. Thus, the austenite at these lower peak temperatures contains areas of high alloy content and low alloy content. In addition, the austenite microstructure is fine grained. At intermediate peak temperatures, the homogeneity and the grain size of austenite are between these extremes. On cooling, the austenite decomposition temperature and decomposition products depend on the local chemistry and the grain size as well as the cooling rate. Non-uniform volumetric changes caused by non-uniform heating of the base and deposit metal, shrinkage of molten metal after welding also lead to internal residual welding stress.

In the whole, a complex steel weld microstructure which consists of two or more micro constituents is formed. Most often micro constituents such as: proeutectoid ferrite, polygonal ferrite, aligned and non-aligned side plate ferrite, ferrite carbide aggregates and acicular ferrite are formed [2 - 4]. Sometimes, upper and lower bainites, martensites and the A-M (austenite with martensite) micro constituents may be formed $[5,6]$. This complex microstructure mixture can lead to highly varied properties of the weld $[3,7]$. A way to unify the structure of the welds is by heat treatment. When the presence of martensite may cause embrittlement, tempering is employed to improve the strength and toughness of the material.

In this study, the effects of tempering heat treatment on mechanical properties and microstructure of plain carbon steel weld is investigated.

\section{EXPERIMENTAL PROCEDURE}

Materials used are 10mm steel rods supplied as-rolled from Universal Steel Rolling Mill, OgbaIkeja, Lagos, Nigeria. These are four (4) different steel which are essentially different in carbon content. The compositions of the steel rods are given in Table $1.150 \mathrm{~mm}$ long pieces were cut from all grades of the steel rods. The middle of each piece was grooved $6 \mathrm{~mm}$ deep and wide using a grinding wheel as illustrated in Figure 1.

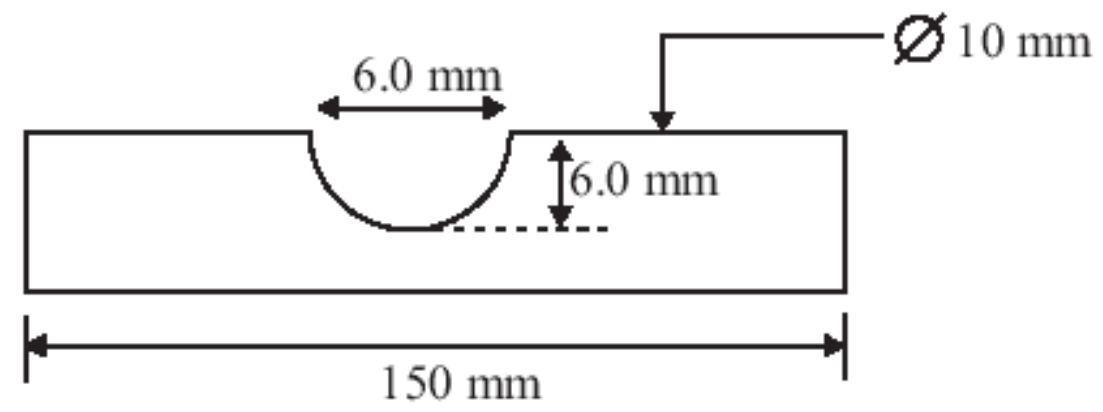

Figure 1: Dimension of grooved specimen. 
Table 1: Composition of steel rods used.

\begin{tabular}{|c|c|c|c|c|}
\hline Element (wt \%) & Sample 1 & Sample 2 & Sample 3 & Sample 4 \\
\hline $\bar{C}$ & 0.2529 & 0.1576 & 0.2756 & 0.3320 \\
\hline Si & 0.1468 & 0.1821 & 0.1769 & 0.3116 \\
\hline $\mathrm{S}$ & 0.0510 & 0.0598 & 0.0523 & 0.0520 \\
\hline$P$ & 0.0419 & 0.0288 & 0.0275 & 0.0274 \\
\hline Mn & 0.3658 & 0.6440 & 0.6247 & 0.7523 \\
\hline $\mathrm{Ni}$ & 0.1034 & 0.1030 & 0.1170 & 0.1110 \\
\hline $\mathrm{Cr}$ & 0.889 & 0.1224 & 0.1306 & 0.1750 \\
\hline Mo & 0.0177 & 0.0114 & 0.0141 & 0.0170 \\
\hline V & 0.0003 & 0.001 & 0.0013 & 0.003 \\
\hline $\mathrm{Cu}$ & 0.3213 & 0.3380 & 0.3949 & 0.2773 \\
\hline W & 0.0023 & 0.0007 & 0.0007 & 0.0043 \\
\hline As & 0.0053 & 0.0033 & 0.0033 & 0.0045 \\
\hline Sn & 0.0278 & 0.0797 & 0.0797 & 0.0268 \\
\hline Co & 0.0098 & 0.0086 & 0.0086 & 0.0094 \\
\hline $\mathrm{Al}$ & 0.0049 & 0.0025 & 0.0025 & 0.0025 \\
\hline $\mathrm{Pb}$ & 0.0012 & 0.0003 & 0.0003 & 0.0017 \\
\hline $\mathrm{Ca}$ & 0.0004 & 0.0001 & 0.0001 & 0.0005 \\
\hline $\mathrm{Zn}$ & 0.0033 & 0.0069 & 0.0069 & 0.0061 \\
\hline $\mathrm{Fe}$ & 98.5550 & 98.2505 & 98.2505 & 97.8859 \\
\hline
\end{tabular}

The grooved samples were then filled in the course of welding to create a weld. AWS E 6013 electrodes were used with a.c. arc welding process. The current used was $100 \mathrm{~A}$ with a terminal voltage of $80 \mathrm{~V}$. Eight pieces of welds were prepared in all, two from each grade of steel. A set 
of four welds were untreated and kept as control, the other set was then tempered at $640{ }^{\circ} \mathrm{C}$ for 60 minutes using Deguassa-Durferrit furnace.

Hardness values of the welds were determined using a LECO micro-hardness tester which uses a diamond indenter. The test load was $98.07 \mathrm{mN}$ (10gf) and the dwell time was 10 seconds. The LECO micro-hardness tester automatically calculates the hardness values in Vickers hardness (VHN). The hardness values of the steel welds were evaluated at three points: (i) the weld pool region (ii) the weld pool and base metal junction (iii) the heat affected zone (HAZ) see fig. 2.

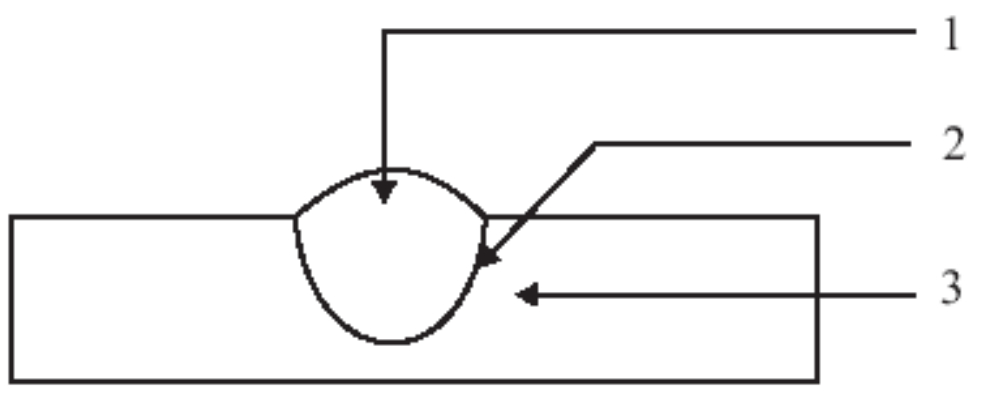

Figure 2: Hardness test specimen (1) Weld pool, (2) Weld pool and base metal junction, (3) Heat Affected Zone (HAZ)

The toughness values were determined from notched specimen of circular cross section prepared from the steel welds. The specimens were notched at the required points to evaluate their toughness at those points. Micro-examination of the steel welds was carried out with optical microscopy. The microstructures were captured with an Olympus metallurgical microscope which has a minisee optical viewing system connected to a computer

\section{RESULT AND DISCUSSION}

Tables 2 to 5 were used to generate Figures 3 to 6 . Figures 3 and 4 show the variation of the hardness values, while Figs. 5 and 6 show the toughness values of the specimen along the weld. These figures show a general trend for each of the tempered samples. There is increase in hardness values with increase in carbon content, while the toughness decreased.

This is also the trend for the untreated samples. Normally, the structure of the steels investigated, viz: $0.16 w t \% C, 0.25 w t \% C, 0.28 w t \% C$ and $0.33 w t \% C$ are essentially ferritic. Ferritic structures could be: proeutectoide ferrite, polygonal ferrite, aligned and non-aligned side plate ferrite, ferrite carbide aggregates, acicular ferrite, bainitic etc [2]. IIW DOC IX-1533-88 [2] gives a detailed classification of weld metal microstructures. The maximum solubility of carbon in ferrite is $0.025 w t \% C[8,9]$. This suggests that the ferritic structures in the investigated steels 
were supersaturated with carbon. This saturation leads to straining of the ferrite matrix and thus consequently leading to increase in hardness values with increase in carbon content. The higher the carbon content, the higher the straining. The straining of the ferritic structure is actually evidenced by Figs. 7 A2 and 7 A3 which show bainitic structures. Bainitic structures are actually fine dispersion of iron carbide in a strained ferrite matrix [9]. The lower toughness of the weld metal with increase in carbon content is also a result of this straining.

Table 2: Vickers hardness values for untreated samples

\begin{tabular}{lllll}
\hline \multicolumn{5}{c}{ Vickers Hardness Value } \\
\hline Sample & $\begin{array}{l}\text { Carbon } \\
\text { content }\end{array}$ & Weld pool & Weld pool and parent metal & HAZ \\
1 & 0.16 & 230 & 543 & 805 \\
2 & 0.25 & 243 & 553 & 827 \\
3 & 0.28 & 281 & 566 & 874 \\
4 & 0.33 & 296 & 570 & 892 \\
\hline
\end{tabular}

Table 3: Vickers hardness values for tempered samples

Vickers Hardness Value

\begin{tabular}{lllll}
\hline Sample & $\begin{array}{l}\text { Carbon } \\
\text { content }\end{array}$ & $\begin{array}{l}\text { Weld pool } \\
\text { zone }\end{array}$ & $\begin{array}{l}\text { Weld pool and parent metal } \\
\text { junction }\end{array}$ & HAZ \\
1 & 0.16 & 213 & 521 & 796 \\
2 & 0.25 & 230 & 546 & 813 \\
3 & 0.28 & 273 & 553 & 859 \\
4 & 0.33 & 285 & 560 & 872 \\
\hline
\end{tabular}


Table 4: Toughness values of untreated samples

\section{Toughness values (J)}

\begin{tabular}{|c|c|c|c|c|}
\hline Sample & $\begin{array}{l}\text { Carbon } \\
\text { content }\end{array}$ & $\begin{array}{l}\text { Weld pool } \\
\text { zone }\end{array}$ & $\begin{array}{l}\text { Weld pool and parent metal } \\
\text { junction }\end{array}$ & HAZ \\
\hline 1 & 0.16 & 20.16 & 15.6 & 8.32 \\
\hline 2 & 0.25 & 18.32 & 12.6 & 7.78 \\
\hline 3 & 0.28 & 16.6 & 11.64 & 6.02 \\
\hline 4 & 0.33 & 15.84 & 9.8 & 4.84 \\
\hline
\end{tabular}

Table 5: Charpy toughness for tempered samples

\section{Toughness values (J)}

\begin{tabular}{|c|c|c|c|c|}
\hline Sample & $\begin{array}{l}\text { Carbon } \\
\text { content }\end{array}$ & $\begin{array}{l}\text { Weld pool } \\
\text { zone }\end{array}$ & $\begin{array}{l}\text { Weld pool and parent metal } \\
\text { junction }\end{array}$ & HAZ \\
\hline 1 & 0.16 & 23.59 & 16.4 & 8.82 \\
\hline 2 & 0.25 & 22.48 & 13.52 & 8.29 \\
\hline 3 & 0.28 & 20.56 & 11.90 & 6.52 \\
\hline 4 & 0.33 & 17.71 & 10.2 & 5.56 \\
\hline
\end{tabular}

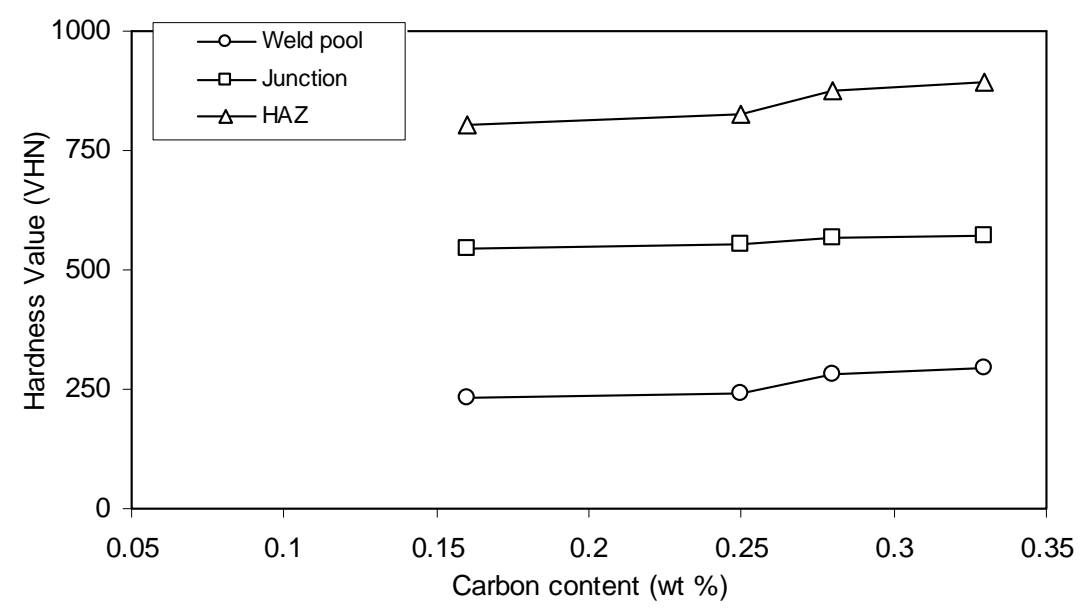

Figure 3: Variation of hardness with carbon content for untreated sample 


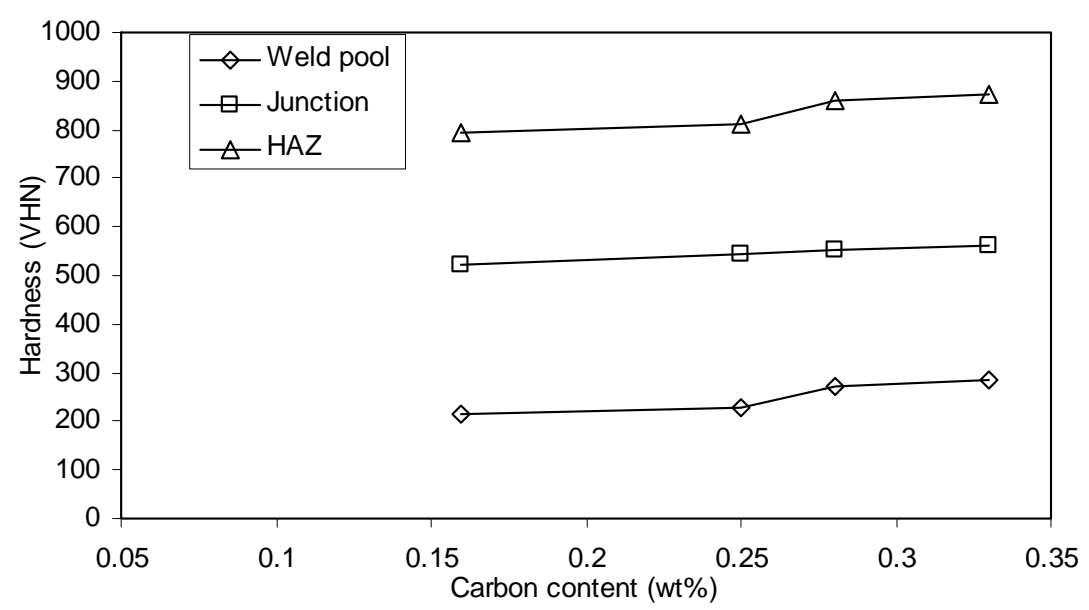

Figure 4: Variation of hardness values with carbon content for tempered samples

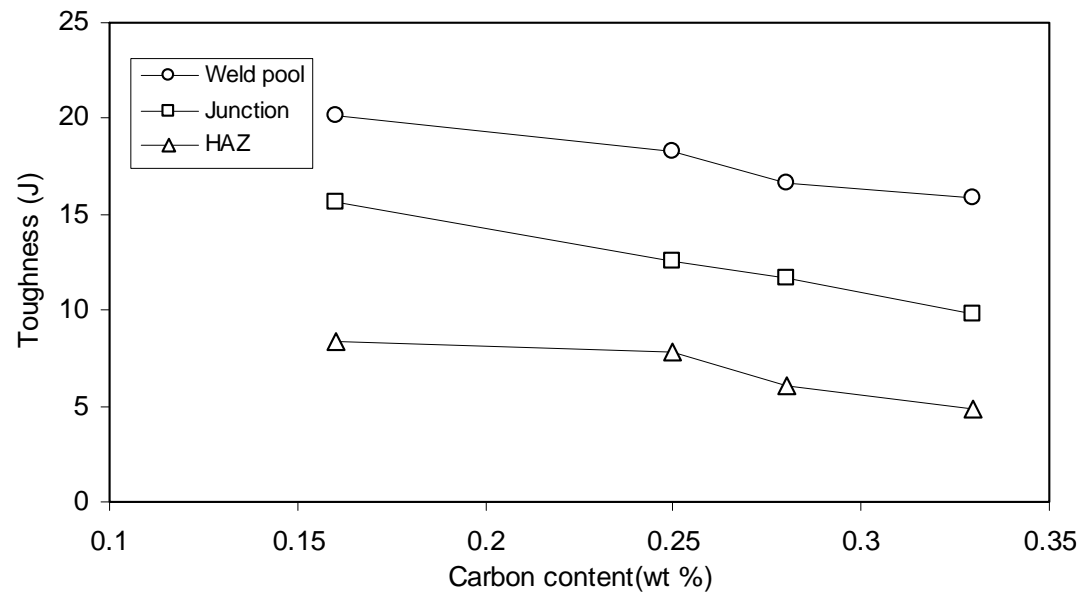

Figure 5: Variation of toughness with carbon content for untreated samples

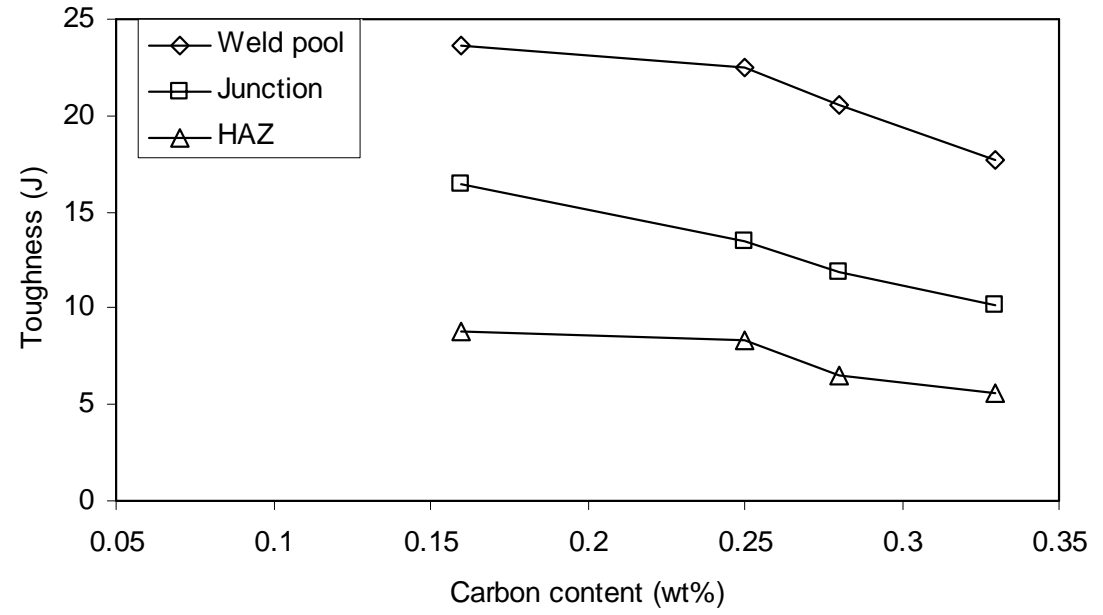

Figure 6: Variation of toughness with carbon content for tempered samples 


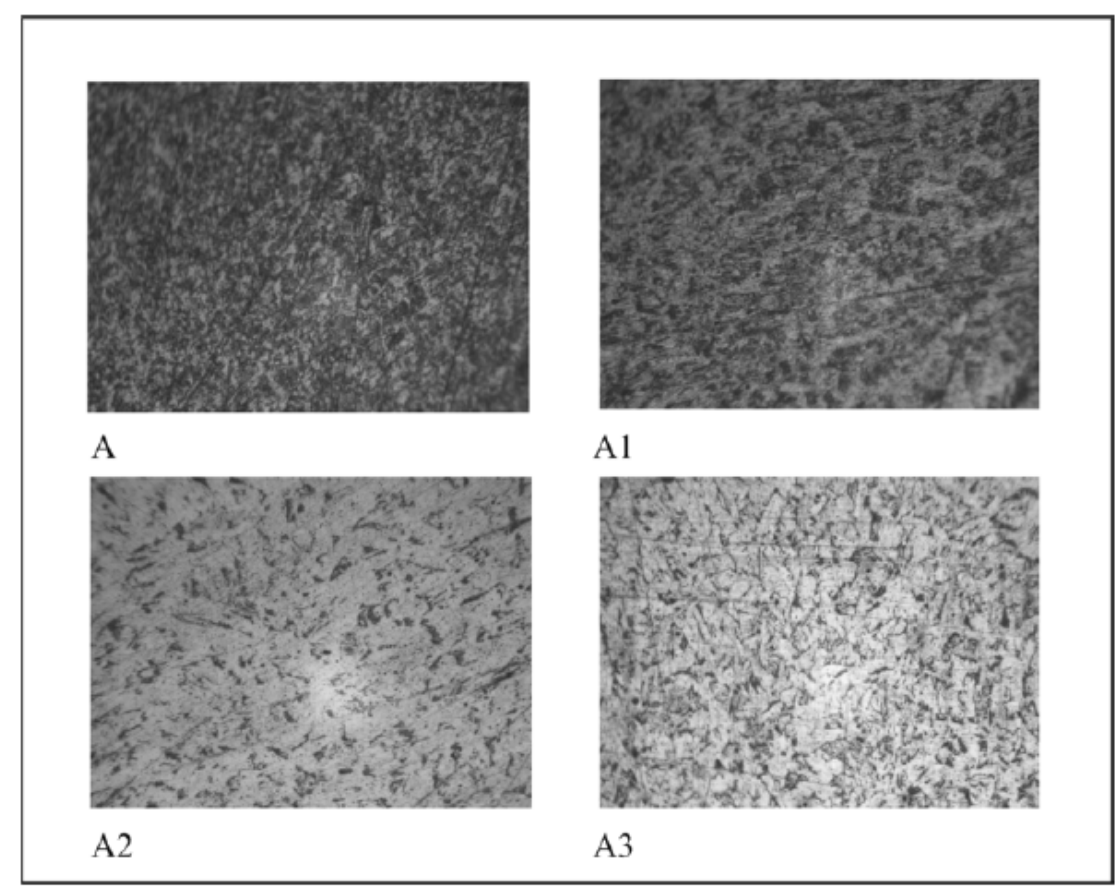

Figure 7: Microstructure of untreated steel welds: (A) $0.16 \mathrm{wt} \% \mathrm{C}$, (A1) $0.25 \mathrm{wt} \% \mathrm{C}$, (A2) $0.28 w t \% C$, (A3) $0.33 w t \% C$

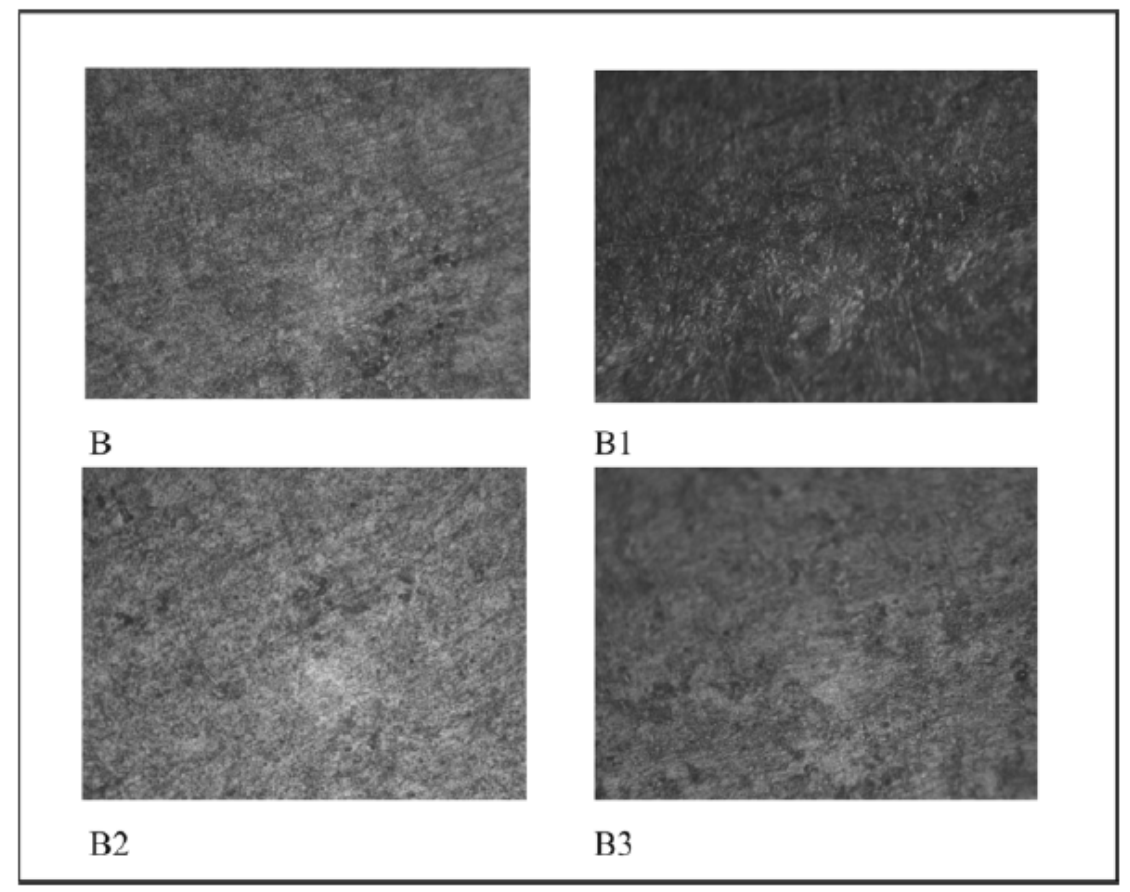

Figure 8: Microstructure of tempered steel welds: (A) $0.16 \mathrm{wt} \% \mathrm{C}$, (A1) $0.25 \mathrm{wt} \% \mathrm{C}$, (A2) $0.28 w t \% C$, (A3) $0.33 w t \% C$ 
By comparing the values of Figs. 3 and 4, Figs. 5 and 6, it is obvious that the trend is decreasing, i.e. hardness values decrease from Fig 3 to Fig. 4 while it increased from Fig. 5 to Fig. 6. Figures 4 and 6 are for the tempered samples, while Figs. 3 and 5 are for the untreated samples. Generally, the values for the tempered samples are minimal for hardness and maximum for toughness. During tempering heat treatment, there is ejection of carbon from the super saturated ferrite matrix $[7,10]$. This leads to the softening of the ferrite matrix. Also any A-M (Austenite with Martensite) phases present are converted to ferrite by losing carbon through diffusion process. Furthermore, the tempering temperature employed $\left(640{ }^{\circ} \mathrm{C}\right)$ is equivalent to that used in recrystallization annealing [11-13], as a result, there is nucleation and growth of new crystals due to recrystallization. Figure 8 (B, B1, B2, B3) which reveals micrographs with finer crystals compared to Fig. 7 (A, A1, A2, A3) which are more coarse confirms that recrystallization actually took place during the tempering heat treatment. The structural modification from coarse to fine structure after tempering heat treatment is also responsible for the increased toughness observed.

Also, apart from straining due to saturation by carbon atoms which are relieved, residual stresses in the welds are also relieved during tempering. Normally, arc welding process can induce residual stresses in the weld during the course of welding. Also, it is obvious that the hardness values increased from the weld pool through to the heat affected zone (HAZ) where the hardness values are higher. The toughness however decreased. Generally, the electrodes have low carbon content; however, there is carbon pick-up in the weld pool due to dilution and solid state diffusion from the base metal. The higher the carbon diluted and/or diffused into the weld pool, the higher the hardness values.

\section{CONCLUSION AND RECOMMENDATION}

The result of the research shows that the hardness and toughness values of the specimen varies with the carbon contents of the specimen. Generally, there was increase in hardness values with increase in carbon content while toughness decreased. It was also found out that the hardness values were minimal at the weld pool compared to the HAZ. It is the other way round for toughness. Tempering significantly affects the microstructure and thus the mechanical properties of the weld.

The range of steels investigated in this work excludes high carbon steels. Further experiment should be carried out to investigate this range of steels.

\section{ACKNOWLEDGEMENT}

The authors wish to thank Mr Adepoju O. Elijah of the Universal Steels Rolling Mill, OgbaIkeja, Lagos, Nigeria, for the help in providing the metallurgy steel rods. The authors further 
wish to convey their gratitude to the Engineering Materials Development Institute (EMDI) Akure, Ondo State Nigeria for offering the distinguished opportunity to use the institute's LECO micro-hardness tester.

\section{REFERENCES}

[1] AWS 1997 American Welding Society welding Handbook, $8^{\text {th }}$ ed. New York.

[2] IIW 1988 International Institute of Welding, Guidelines for the classification of ferrite steel weld metal microstructure constituents using the light microscopy, International Institute of Welding, IIW DOC. IX-1533-88.

[3] Adedayo, A.V., Ibitoye, S.A., Oyetoyan, O.A. 2010 Annealing Heat Treatment Effects on Steel Welds. Journal of Mineral, Materials Characterization and Engineering, Vol. 9, No. 6 pp 547-557.

[4] da Trindade Filho V.B., A.S. Guimaraes, J. da C. Payao Filho, R.P. da R. Paranhos 2004 Normalizing heat treatment effects on low alloy steel weld metals. Journal of Brazilian Society of Mechanical Sciences and Engineering, Vol. 26., No. 1

[5] Grong, O. 1992 Microstructure and properties of steel weld metals in : D.L. Olson and T.H. North (eds. ) Ferrous Alloys Weldments Transaction Technical Publications. Pp 2146.

[6] Evans, G.M. 1991 The effects of Nickel on microstructure and properties of C-Mn allweld metal deposits. Welding Research Abroad, 37, Vol. 41

[7] Adedayo, A.V. 2009 Effects of Carbon Content on Steel Welds. Journal of Research in Technology and Engineering Management, Vol. 2, No. 1 pp131-135

[8] Higgins, R.A. 1998 Properties of engineering materials, $2^{\text {nd }}$ ed., Viva books, Private Ltd, New Delhi.

[9] Brophy, J.H., Rose, R.M.; Wulff J., 1964 The structure and properties of materials, thermodynamics, vol.2, John Wiley and Sons, Brisbane, pp 113-114, 188-189

[10] Rajan, T.V.; Sharma C.P.; Sharma A. 1988 Heat treatment principles and techniques; prentice-Hall of India, Private Ltd. New Delhi, pp289.

[11] Rajput, R.K. 2006 Engineering materials and metallurgy, $1^{\text {st }}$ ed. S. Chand \& Co. New Delhi. pp. 66

[12] DeGarmo, E.P.; Black, J.T.; Kosher, R.A. 2003 Material and Processes in Manufacturing $9^{\text {th }}$ ed. John Wiley and Sons, New York, pp 84

[13] DeGarmo, E.P.; Black, J.T.; Kosher, R.A. 1999 Material and Processes in Manufacturing $8^{\text {th }}$ ed. John Wiley and Sons, New York, pp 112 